\title{
Perancangan, Implementasi Monitoring dan Kontrol Alat Pemanggang Kopi
}

\author{
Friyogi Tampubolon ${ }^{1)}$, Yohanssen Pratama*2), and I Gde Eka Dirgayussa ${ }^{3)}$ \\ 1,2,3) Department of Informatics and Electrical Engineering, Institut Teknologi Del, Toba, Indonesia \\ Corresponding Email: *) yohanssen.pratama@del.ac.id
}

\begin{abstract}
Coffee roasting is the process of removing the water that is exist in the coffee beans. Roasted coffee beans will change weight and give a nice aroma and taste. The longer the coffee beans are roasted, the color of the coffee beans will continue getting darker blackish brown. The roasting level of coffee beans is determined from the change in color of coffee beans starting from light, medium and dark. Roasting coffee beans that develop on a home industry scale is still manual, that is, using more human labor in its operation. Therefore, this research will be made an automatic coffee roasting machine using a heater to heating the coffee beans, a DC motor to stir roasted coffee beans and a webcam to monitor changes in the color of coffee beans when roasted. Components of heating elements and motors controlled by Arduino Mega 2560 microcontroller while the webcam is connected with Raspberry $\mathrm{Pi} 3$. As a component of performance that has been met with sensors as data collectors, microcontrollers as data processors and actuators as control systems. In this researh $3 \mathrm{D}$ modeling for a roasting container is done using SketchUp 3D design software. The results of the coffee roasting machine can meet the requirements of the system designed in accordance with the roasting level desired by the user and the thermocoupel give a better result in reading the temperature parameter compared to infrared thermometer. In 4,5 minutes the difference reading in temperature reach $27,5^{\circ} \mathrm{C}$ between two sensors.
\end{abstract}

Key words: Automation, control, power systems, energy.

\section{Pendahuluan}

Menyangrai kopi (roasting coffee) adalah proses mengeluarkan air dari dalam kopi, mengeringkan dan mengembangkan bijinya, mengurangi beratnya memberikan aroma pada kopi tersebut. Ketika kopi dimasak ada suatu reaksi kimia yang menyertai sehingga karakter biji kopi pun berubah. Semakin lama biji kopi dimasak, semakin banyak bahan kimia yang berubah karakteristiknya. Ketika kopi di-roasting, kopi berubah menjadi berwarna coklat. Oleh karena itu, semakin lama proses roasting maka akan menghasilkan biji kopi yang berwarna lebih gelap. Namun bagaimanapun, meroasting biji kopi bukanlah suatu hal yang sederhana, sesederhana memasukkannya ke alat pemanggang dan kemudian me-roastingnya. Biji kopi sesungguhnya akan menghasilkan kopi yang berbeda apabila di-roasting dalam suhu yang berbeda meskipun hasil akhirnya berwarna sama [1]. Secara umum, pemanggangan biji kopi dibagi atas 3 tingkat kematangan yaitu light, medium dan dark [1]. Ketiga tingkat pemanggangan ini memiliki suhu pemanggangan, warna kopi, waktu dan kecepatan pengadukan yang berbeda. Pada saat pemanggangan, suhu pemanggangan dan kecepatan pengaduk harus dikendalikan supaya tetap konstan sesuai dengan tingkat pemanggangan yang diinginkan. Begitu juga dengan webcam yang dipasang pada mesin pemanggangan untuk memantau kematangan biji kopi secara realtime.

Berdasarkan hal tersebut, maka dalam penelitian ini dirancang sebuah mesin pemanggangan kopi otomatis yang dapat membantu pengguna/roaster dalam melakukan pemanggangan. Pada penelitian ini, penulis berfokus pada perancangan mesin pemanggang kopi. Perancangan produk dibuat menggunakan teknik pemodelan 3D yang kemudian diimplementasikan ke dalam bentuk nyata. Seluruh perancangan yang dibuat dapat memenuhi sistem yang dibangun pada produk mesin pemanggangan kopi tersebut.

\section{Metodologi}

\section{A. Analisis Alat pada Produk}

Penelitian yang dilakukan tergolong dalam penelitian terapan. Penelitian terapan adalah penelitian yang bertujuan untuk memecahkan masalah-masalah kehidupan praktis. Dalam penelitian yang dikerjakan, permasalahan yang ingin diselesaikan adalah bagaimana proses pemanggangan dapat berlangsung sesuai dengan desain alat yang sudah dibuat.

Dalam proses pembuatan mesin penyangrai kopi ini dibutuhkan diagram alir yang bertujuan untuk memperjelas tahapan-tahapan dalam proses pembuatan alat yang digunakan pada mesin penyangrai tersebut. Hal ini perlu dilakukan untuk memudahkan dalam perancangan dan pembuatan alat-alat yang digunakan pada mesin penyangrai tersebut.

Hal pertama yang dilakukan adalah menganalisis permasalahan kemudian membuat rancangan dari solusi yang sudah didapatkan dari analisis permasalahan. Kemudian melakukan implementasi dari solusi tersebut. Setelah itu, dilakukan uji alat yang sudah dirancang untuk mengetahui kualitas dari alat yang sudah dirancang. Jika kualitas alat dalam me-roasting kopi belum tercapai, maka akan dibuat lagi rancangan perbaikan. Jika sudah berhasil maka alat tersebut akan digunakan me-roasting kopi. 


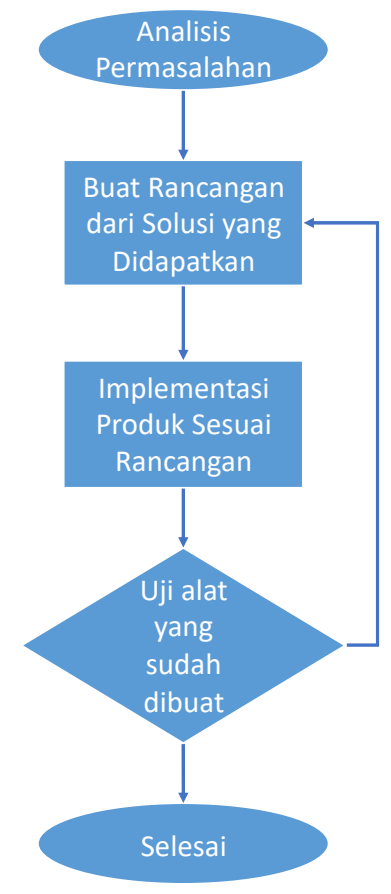

Gambar 1.Diagram Alir Pembuatan Mesin Penyangrai Kopi

Untuk mendapatkan produk yang sesuai dengan hasil rancangan, pertama-tama dilakukan analisis permasalahan yaitu untuk mengetahui permasalahanpermasalahan yang ada pada mesin tersebut. Pada penelitian yang sudah dilakukan, permasalahanpermasalahan yang didapatkan antara lain:

1. Alat untuk memutar kopi didalam wadah.

2. Alat untuk mengatur suhu selama pemanggangan.

3. Alat untuk memantau kopi selama pemanggangan.

4. Suku cadang untuk mengganti komponen yang sudah rusak atau mengalami penurunan performa.

Hal yang dilakukan setelah menemukan permasalahan tersebut adalah untuk menemukan rancangan solusi. Adapun solusinya adalah sebagai berikut:

1. Alat yang digunakan untuk memutar kopi didalam wadah adalah motor DC dan blade. Motor DC akan dihubungkan dengan blade yang kemudian akan menggerakkan blade Komponen yang digunakan untuk mengontrol motor DC adalah driver motor dan mikrokontroller yaitu Arduino Mega 2560 [2].

2. Selanjutnya alat yang digunakan untuk mengatur suhu pemanggangan adalah termokopel tipe K, thermometer infrared, heater, relay dan modul MAX6675. Untuk sensor termokopel tipe K terbuat dari (Chromel (Ni-Cr alloy) / Alumel (Ni-Al alloy) dapat mendeteksi suhu dari $-200^{\circ} \mathrm{C}$ sampai $+1250^{\circ} \mathrm{C}$ sedangkan untuk thermometer infrared dapat mendeteksi suhu mulai dari $-50^{\circ} \mathrm{C}$ sampai $+700^{\circ} \mathrm{C}$. Dilihat dari range suhunya, maka kedua sensor suhu yang digunakan masih dapat menghitung suhu maksimal yang diperlukan untuk mendapatkan tingkat kematangan dark roast yaitu sekitar $+240^{\circ} \mathrm{C}$. Termokopel akan diletakkan pada bagian bawah dan sisi wadah untuk dapat mengetahui suhu pemanggangan. Sedangkan relay akan mengatur hidup matinya heater. Tujuannya untuk menahan heater tetap pada suhu yang diatur. Kemudian modul MAX6675 adalah untuk mengukur tegangan dari output termokopel yang akan dikirimkan ke mikrokontroller Arduino Mega 2560 [3].

3. Lalu alat yang digunakan untuk memantau pemanggangan adalah webcam dan Raspberri Pi 3. Proses pemanggangan kopi memiliki beberapa tingkat kematangan yaitu, kematangan pada level light, level medium dan level dark. Level dark memiliki karakteristik yang paling berbeda dari kedua level tersebut. Pada level dark kopi berwarna hitam namun tidak hangus, struktur yang ringan dan pada permukaan kopi berminyak. Pada level light dan level medium kopi berwarna kecokelatan dan tidak ada minyak pada permukaan kopi, namun pada level medium kopi berwarna sedikit lebih kecokelatan dari kopi level light (Gambar 2).

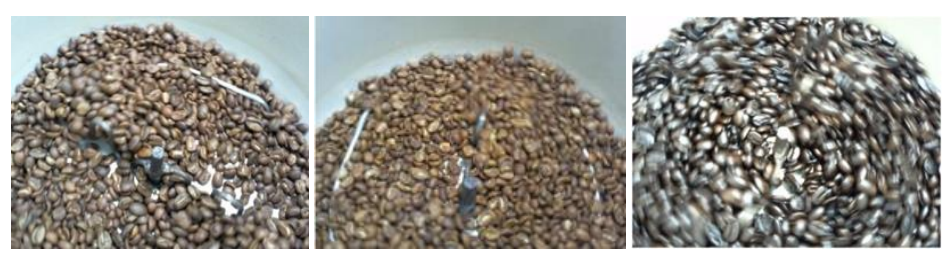

Gambar 2.Warna biji kopi yang ditangkap webcam (berurut dari kiri ke kanan mulai dari light, medium, dark)

4. Kemudian dikarenakan adanya kemungkinan kerusakan pada Raspberry Pi 3 yang disebabkan oleh low voltage (menyebabkan tegangan keluaran dari beberapa GPIO pada Raspberry sebesar $0 \mathrm{~V}$ yang seharusnya adalah $3.3 \mathrm{~V}$ ). GPIO adalah pin atau terminal tambahan input output yang khusus dipasang diboard raspberry pi untuk koneksi ke perangkat luar. Sehingga untuk mengatasi hal ini maka dilakukan penambahan mikrokontroller yaitu Arduino Mega 2560.

\section{B. Perancangan Produk}

Perancangan produk memberikan gambaran fisik dari produk yang dibuat. Berdasarkan perancangan yang dibuat, produk ini terdiri wadah, sensor, motor dan blade, webcam dan kerangka penyangga yang sudah dirancang secara keseluruhan. Perancangan ini sudah dibuat untuk dapat diimpelentasikan dalam bentuk nyata. Perancangan produk ini dibuat dengan menggunakan software SketchUp dalam bentuk pemodelan 3D. Kemudian setiap komponen penyusun produk, akan dibuat rangkaian masing-masing komponen yang akan diimplementasikan pada produk tersebut.

Berdasarkan Gambar 3, bagian elemen pemanas tidak terlihat dikarenakan elemen pemanas berada di bagian bawah (tertutupi oleh wadah). Kerangka penyangga terbuat dari besi supaya dapat menahan panas dan tidak terbakar ketika berada disuhu yang tinggi dan wadah terbuat dari aluminium. Diantara kerangka penyangga dan elemen pemanas ditambahkan keramik sebagai isolator agar dapat menahan panas dari elemen pemanas dan tidak langsung membuat kerangka penyangga cepat panas. 


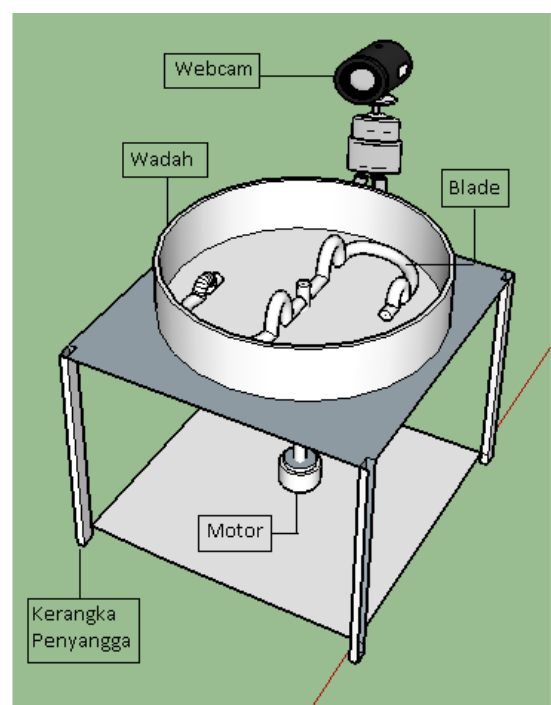

Gambar 3. Bentuk Rancangan Produk Keseluruhan

1. Rangkaian Motor dan Blade Pengaduk ke Arduino Mega 2560

Motor DC dihubungkan dengan blade pengaduk yang kemudian akan memutar biji kopi didalam wadah. Agar motor DC dapat bekerja, motor harus dihubungkan dengan driver motor dan Arduino Mega 2560. Rangkaian motor akan dihubungkan ke jala-jala agar motor dapat berputar. Arduino Mega 2560 nantinya akan mengirim perintah ke driver motor agar motor dapat berputar. Kontrol dari motor DC juga dikendalikan oleh Arduino Mega 2560 (gambar 4).

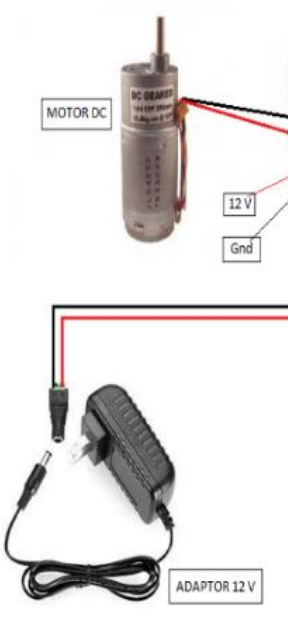

Gambar 4. Rangkaian Motor dan Blade Pengaduk

2. Rangkaian Elemen Pemanas dan Relay ke Arduino Mega 2560

Elemen pemanas atau heater akan dihubungkan ke relay. Kemudian relay dihubungkan ke Arduino Mega 2560. Nantinya suhu pemanggangan akan diatur oleh Arduino Mega 2560 dengan cara mengirimkan sinyal ke relay untuk mengaktifkan ataupun menonaktifkan heater (Gambar 5).

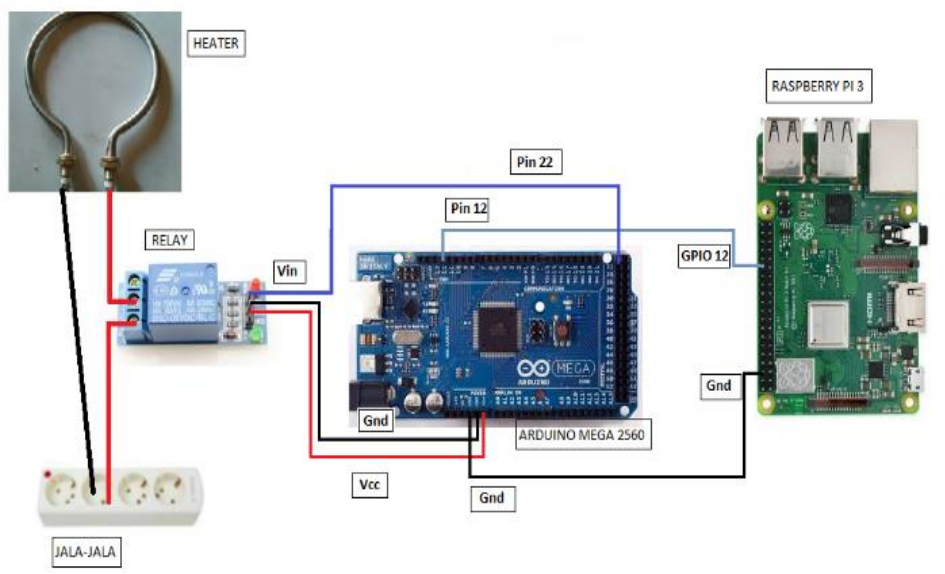

Gambar 5. Rangkaian Elemen Pemanas dan Relay

3. Rangkaian Display ke Arduino Mega 2560

Kondisi suhu pemanggangan, status heater dan status motor akan ditampilkan pada LCD [4]. Pengguna juga dapat melihat menu tingkat kematangan biji kopi yang ingin dipanggang melalui LCD. Jika pengguna ingin memilih tingkat kematangan yang diinginkan, maka pengguna tinggal menekan tombol keypad yang telah disediakan. Untuk pemanggangan dengan tingkat kematangan light, maka pengguna menekan tombol 1 untuk pemanggangan dengan tingkat kematangan medium, maka pengguna menekan tombol 2 , dan untuk pemanggangan dengan tingkat kematangan dark, maka pengguna menekan tombol 3 (gambar 6). Perbedaan pengaturan dari tombol 1,2, dan 3 terletak pada range suhunya, untuk tombol 1 adalah light roast dimana suhu disetting antara $180-205^{\circ} \mathrm{C}$, tombol 2 adalah medium roast suhu pemanggangan antara $210-220^{\circ} \mathrm{C}$, dan tombol 3 adalah dark roast untuk suhu disetting pada angka $240^{\circ} \mathrm{C}$.

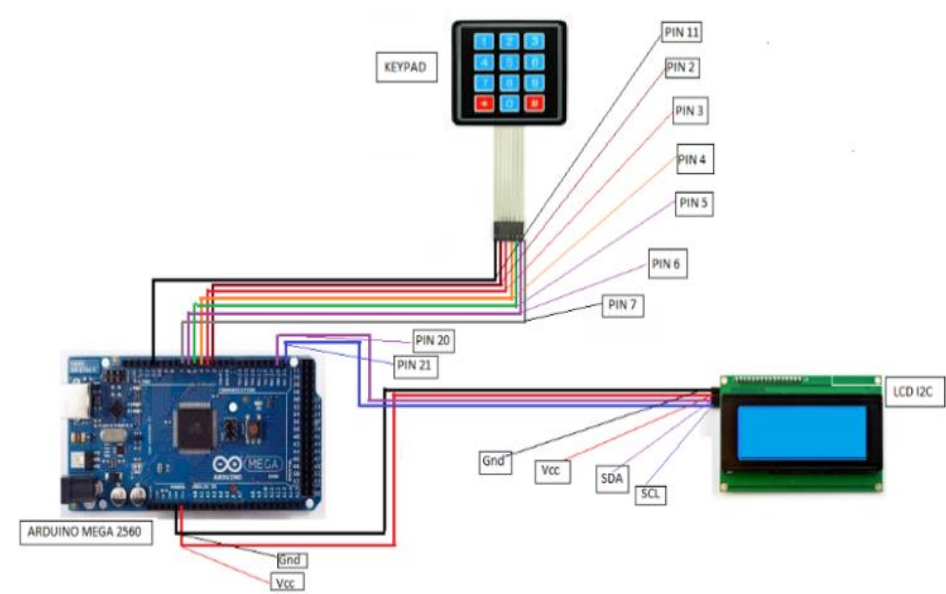

Gambar 6. Rangkaian LCD dan Keypad

4. Rangkaian Webcam ke Raspberry Pi 3

Webcam berfungsi untuk memantau warna biji kopi selama pemanggangan. Apabila webcam menangkap warna biji kopi dengan tingkat kematangan tertentu, maka Raspberry akan memberi 
sinyal LOW ke Arduino untuk mematikan motor DC dan elemen pemanas tersebut (Gambar 7).

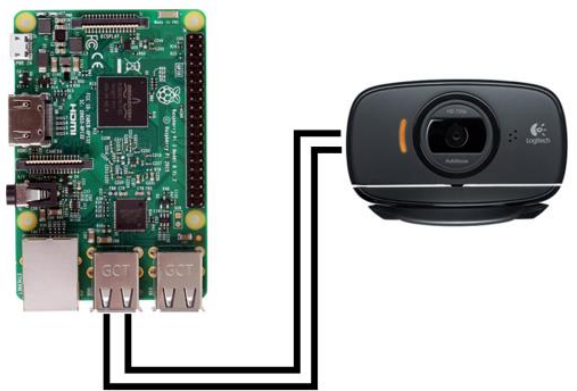

Gambar 7. Rangkaian Webcam

Berikut adalah perbandingan antara gambar yang diambil secara manual dengan gambar yang diperoleh oleh webcam (Table 1).

Table 1. Hasil perbandingan antara pengambilan gambar manual dengan webcam

\begin{tabular}{|l|c|c|c|}
\hline & Light & Medium & Dark \\
\hline manual & & & \\
\hline webcam & & & \\
& & & \\
\hline
\end{tabular}

\section{Hasil dan Pembahasan}

\section{A. Implementasi Produk}

Berdasarkan perancangan yang sudah dibuat, masingmasing dari sistem yang dirancang tersebut kemudian diimplementasikan. Proses implementasi tersebut meliputi pengaplikasian produk yang dirancang ke dalam bentuk fisik langsung sampai proses pengkabelan perangkat keras (mikrokontroler dan sensor).

Implementasi dari desain alat secara keseluruhan terdiri dari penyangga wadah kopi, wadah kopi, webcam, motor DC, dudukan motor, blade pengaduk, keypad dan LCD. Implementasi keseluruhan sudah berjalan dan berfungsi dengan baik ditandai dengan keseluruhan komponen dapat berfungsi untuk melakukan proses roasting dengan tingkat kematangan tertentu. Implementasi penyangga wadah berfungsi sebagai tempat dudukan wadah, penyangga wadah dibuat dari besi agar mampu menahan panas yang dihasilkan oleh heater. Implementasi wadah berfungsi sebagai tempat pemanggangan kopi, wadah yang digunakan memiliki diameter $25 \mathrm{~cm}$ dan tinggi 15.5 $\mathrm{cm}$ dan biji kopi yang akan dipanggang dimasukkan ke dalam wadah dengan berat kopi 300 gr sampai 500 gr. Implementasi dari motor DC dan blade untuk memutar biji kopi dengan kecepatan yang telah diatur di dalam program. Implementasi keypad sebagai komponen untuk memberikan input dalam memilih tingkat kematangan kopi yang ingin dipanggang. Implementasi LCD untuk menampilkan menu dari tingkat kematangan kopi, keadaan heater, keadaan motor DC, dan untuk menampilkan apakah kopi telah matang, dan penambahan bola lampu untuk membantu penerangan sehingga pencahayaan bisa tetap konstan selama kopi dipanggang. Hasil implementasi produk secara keseluruhan dapat dilihat pada Gambar 8.

Pada saat implementasi, tidak semua hasil rancangan produk yang dibuat dapat diimplementasikan secara keseluruhan. Terdapat perbedaan antara hasil rancangan dengan implementasi produk, tetapi perbedaan tersebut tidak mengurangi kemampuan dari sistem yang dibuat. Perbedaan tersebut terjadi akibat adanya penyesuaian terhadap komponen yang didapatkan di pasaran tetapi diupayakan untuk tetap dapat berfungsi sesuai dengan peruntukannya.

Pada perancangan awalnya Gambar 8, tidak ada lampu sebagai komponen produk ini. Penambahan lampu tersebut adalah untuk penambahan cahaya didalam wadah tersebut agar lebih jelas dipantau oleh webcam. Akan tetapi, perancangan lampu tersebut berhasil diimplementasikan, baik dari segi penempatan dan daya lampu tersebut.
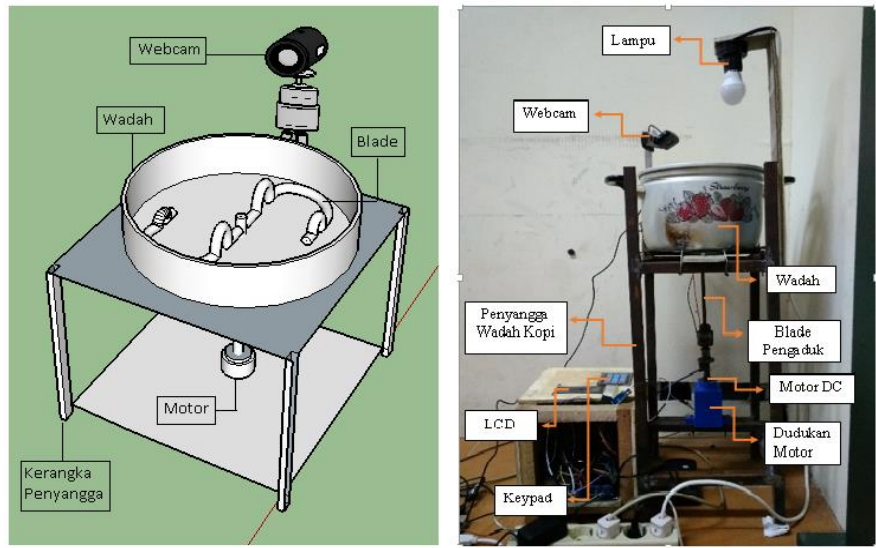

Gambar 8. Perbandingan antara perancangan dengan implementasi produk secara keseluruhan

a. Implementasi Motor DC dan Blade Pengaduk

Motor DC $12 \mathrm{~V}$ berfungsi untuk memutar blade pengaduk [5]. Blade pengaduk nantinya akan dipasangkan pada motor DC dan kecepatannya akan diatur dalam PWM oleh Arduino Mega 2560. Motor DC dipasangkan ke sebuah dudukan motor yang berfungsi mempertahankan perputaran motor (Gambar 9).

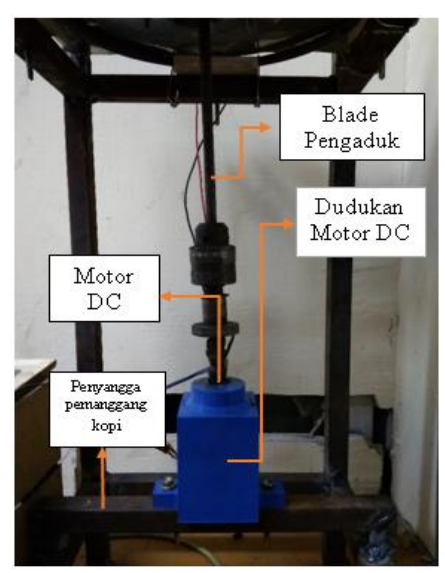

Gambar 9. Implementasi Motor DC 
Kemudian blade pengaduk (Gambar 10) berfungsi untuk mengaduk biji kopi ketika proses pemanggangan sedang berlangsung [6]. Hal ini dilakukan agar biji kopi yang dipanggang memiliki kematangan yang merata.

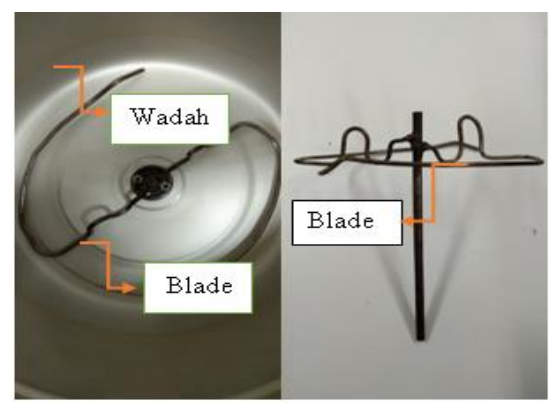

Gambar 10. Implementasi Blade Pengaduk

b. Pengujian Sensor Suhu pada Posisi yang Berbeda

Elemen pemanas atau heater berfungsi untuk memanaskan wadah. Dengan menggunakan Arduino Mega 2560, relay dan sensor suhu maka suhu pemanggangan heater dapat dimonitoring dan dikontrol secara otomatis

- Termokopel dipasang tepat di bagian bawah wadah pemanggang kopi.

Pada lokasi pertama sensor termokopel dipasangkan tepat di bagian bawah wadah pemanggang kopi (gambar 11) [7]. Hasil deteksi suhu antara sensor termokopel dengan thermometer infrared ditunjukkan pada Tabel 2.

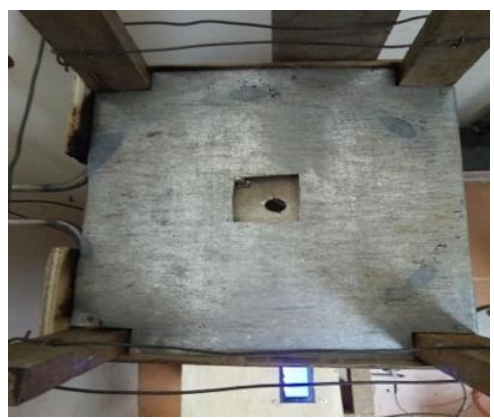

Gambar 11. Sensor Termokopel Dipasang di Bagian Bawah Wadah

Table 2. hasil deteksi suhu menggunakan termokopel dan thermometer infrared pada bagian bawah wadah

\begin{tabular}{ccccc}
\hline $\begin{array}{c}\text { Percobaan } \\
\text { ke- }\end{array}$ & $\begin{array}{c}\text { Detik } \\
\text { ke- }\end{array}$ & $\begin{array}{l}\text { Termokopel } \\
\left({ }^{\circ} \mathrm{C}\right)\end{array}$ & $\begin{array}{c}\text { Thermometer } \\
\text { Infrared }\left({ }^{\circ} \mathrm{C}\right)\end{array}$ & $\begin{array}{l}\text { Perbedaan } \\
\text { Deteksi } \\
\text { Nilai Suhu } \\
\left({ }^{\circ} \mathrm{C}\right)\end{array}$ \\
\hline 1 & 0 & 28.00 & 28.20 & 0.20 \\
\hline 2 & 30 & 30.00 & 30.40 & 0.40 \\
\hline 3 & 60 & 31.50 & 32.10 & 0.60 \\
\hline 4 & 90 & 34.00 & 36.10 & 2.10 \\
\hline 5 & 120 & 40.00 & 43.60 & 3.60 \\
\hline 6 & 150 & 52.75 & 55.60 & 2.85 \\
\hline 7 & 180 & 67.50 & 69.50 & 2.00 \\
\hline 8 & 210 & 83.00 & 88.50 & 5.50 \\
\hline
\end{tabular}

\begin{tabular}{|c|c|c|c|c|}
\hline $\begin{array}{c}\text { Percobaan } \\
\text { ke- }\end{array}$ & $\begin{array}{c}\text { Detik } \\
\text { ke- }\end{array}$ & $\begin{array}{l}\text { Termokopel } \\
\left({ }^{\circ} \mathrm{C}\right)\end{array}$ & $\begin{array}{l}\text { Thermometer } \\
\text { Infrared }\left({ }^{\circ} \mathrm{C}\right)\end{array}$ & $\begin{array}{l}\text { Perbedaan } \\
\text { Deteksi } \\
\text { Nilai Suhu } \\
\left({ }^{\circ} \mathrm{C}\right)\end{array}$ \\
\hline 9 & 240 & 100.25 & 101.60 & 1.35 \\
\hline 10 & 270 & 134.00 & 110.40 & 23.60 \\
\hline
\end{tabular}

Dari data yang telah didapat, dapat dilihat bahwa perbedaan nilai deteksi suhu menggunakan termokopel dan thermometer infrared pada detik ke-0 sampai detik ke-30 sangat kecil. Namun seiring dengan berjalannya waktu, perbedaan nilai yang didapat menjadi semakin besar. Pada detik ke-270 perbedaan deteksi suhu menggunakan menggunakan termokopel dan thermometer infrared mencapai $23.6^{\circ} \mathrm{C}$. Hal ini menunjukkan bahwa terdapat perbedaan nilai yang signifikan apabila sensor dipasang di bagian bawah wadah pemanggang. Menurut pengamatan yang telah dilakukan, perbedaan nilai suhu yang besar ini dapat terjadi karena pemasangan sensor termokopel pada bagian bawah wadah juga berada dekat dengan heater. Hal ini menyebabkan sensor dapat mendeteksi suhu lebih tinggi dibandingkan dengan thermometer infrared dikarenakan material dari sensor termokopel adalah logam yang dapat menyimpan panas untuk waktu yang cukup lama.

- Termokopel dipasang di bagian sisi wadah pemanggang kopi

Termokopel dipasang di bagian sisi wadah pemanggang kopi. Pada lokasi kedua sensor termokopel dipasangkan di salah satu sisi wadah pemanggang kopi. Lokasi pemasangan sensor termokopel pada sisi wadah (Gambar 12).

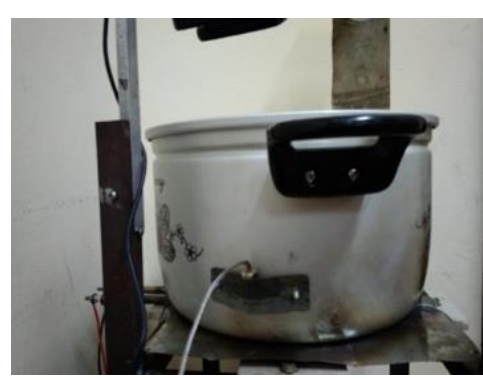

Gambar 12. Sensor termokopel dipasang di salah satu bagian sisi wadah

Pada detik ke 30 (Tabel 3) dapat dilihat bahwa perbedaan pembacaan suhu oleh termokopel yang diletakkan pada bagian wadah dengan di sisi wadah sangat kecil, tetapi jika dilihat pada detik ke 270 maka perbedaannya sangat signifikan, yaitu dengan selisih sebesar $78,44^{\circ} \mathrm{C}$.

Table 3. hasil deteksi suhu menggunakan termokopel dan thermometer infrared pada salah satu sisi wadah

\begin{tabular}{ccrrr}
\hline $\begin{array}{c}\text { Percobaan } \\
\text { ke- }\end{array}$ & $\begin{array}{c}\text { Detik } \\
\text { ke- }\end{array}$ & $\begin{array}{c}\text { Termokopel } \\
\left({ }^{\circ} \mathrm{C}\right)\end{array}$ & $\begin{array}{c}\text { Thermometer } \\
\text { Infrared }\left({ }^{\circ} \mathrm{C}\right)\end{array}$ & $\begin{array}{c}\text { Perbedaan } \\
\text { Deteksi } \\
\text { Nilai Suhu } \\
\left({ }^{\circ} \mathrm{C}\right)\end{array}$ \\
\hline 1 & 0 & 28.75 & 27.90 & 0.85 \\
\hline 2 & 30 & 29.25 & 28.30 & 0.95 \\
\hline 3 & 60 & 29.75 & 28.70 & 1.05 \\
\hline 4 & 90 & 30.00 & 29.10 & 0.90 \\
\hline
\end{tabular}




\begin{tabular}{ccrrr}
\hline $\begin{array}{c}\text { Percobaan } \\
\text { ke- }\end{array}$ & $\begin{array}{c}\text { Detik } \\
\text { ke- }\end{array}$ & $\begin{array}{c}\text { Termokopel } \\
\left({ }^{\circ} \mathrm{C}\right)\end{array}$ & $\begin{array}{c}\text { Thermometer } \\
\text { Infrared }\left({ }^{\circ} \mathrm{C}\right)\end{array}$ & $\begin{array}{c}\text { Perbedaan } \\
\text { Deteksi } \\
\text { Nilai Suhu } \\
\left({ }^{\circ} \mathrm{C}\right)\end{array}$ \\
\hline 5 & 120 & 30.25 & 30.00 & 0.25 \\
\hline 6 & 150 & 31.50 & 32.50 & 1.00 \\
\hline 7 & 180 & 32.75 & 35.10 & 2.35 \\
\hline 8 & 210 & 34.75 & 35.30 & 0.55 \\
\hline 9 & 240 & 46.90 & 47.50 & 0.60 \\
\hline 10 & 270 & 55.56 & 56.10 & 0.54 \\
\hline
\end{tabular}

Dari data yang telah didapat, dapat dilihat bahwa perbedaan nilai deteksi suhu menggunakan termokopel dan thermometer infrared pada posisi kedua terlihat lebih stabil daripada posisi pertama. Perbedaan nilai suhu pada detik ke-0 sampai detik ke-270 berada di kisaran 0.5 sampai 0.85 yang artinya perbedaan nilainya sangat kecil. Pada beberapa waktu percobaan misalnya pada detik ke120 dan detik ke-180, perbedaan nilai suhu yang dideteksi bernilai 1.05 dan 2.35. Namun pada detik selanjutnya sampai pada detik ke-270 perbedaan nilai suhunya berada pada nilai 0.54. Dari percobaan ini dapat dilihat bahwa pemasangan sensor termokopel pada posisi kedua menghasilkan deteksi nilai suhu yang jauh lebih baik dan lebih stabil, sehingga diputuskan lokasi pemasangan sensor untuk mendeteksi suhu pemanggangan dibuat di sisi wadah pemanggangan. Perbedaan pembacaan nilai suhu disebabkan oleh perbedaan posisi ukur, karena kapasitas sensor pembaca suhu baik untuk termokopel maupun thermometer infrared masih berada pada jangkauan yang diperlukan untuk memanggang kopi $\left(25^{\circ} \mathrm{C}-240^{\circ} \mathrm{C}\right)$.

\section{- Implementasi Display}

Implementasi tampilan menggunakan LCD dengan ukuran 4x20. LCD akan menampilkan tiga pilihan tingkat kematangan biji kopi yang ingin dipanggang. Untuk pemilihan menu, pengguna dapat memilih menu dengan menekan tombol keypad. Tombol 1 untuk kematangan light, tombol 2 untuk kematangan medium dan tombol 3 untuk kematangan dark

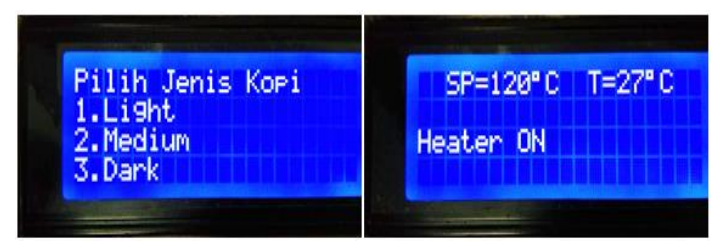

Gambar 12. Implementasi LCD

\section{- Implementasi aplikasi}

Pengujian alat untuk memanggang biji kopi dilakukan pada tingkat kematangan medium dan dark dengan menggunakan aplikasi. Pengujian alat untuk memanggang biji kopi pada tingkat kematangan medium membutuhkan waktu sekitar 8 jam. Adapun tahapan/prosedur dalam melakukan pengujian pada alat dalam memanggang kopi level medium dapat dilihat pada flowchart Gambar 13.

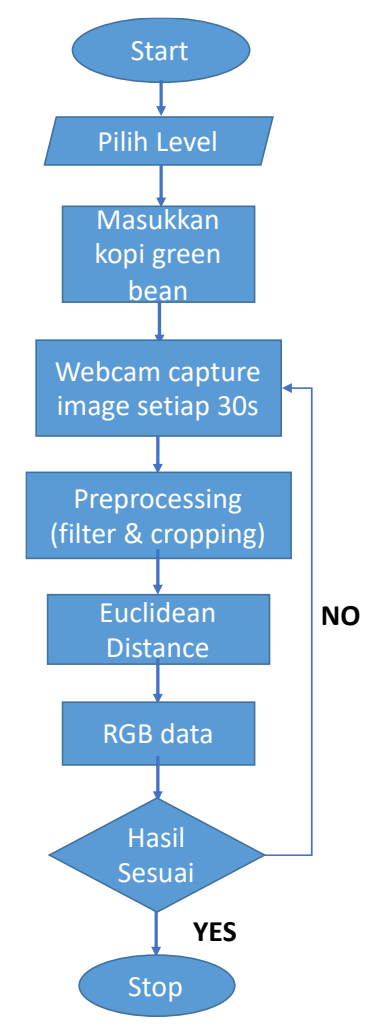

Gambar 13. Flow Process Pemanggangan Kopi pada Level Medium

Di dalam kode program akan dilakukan pengambilan gambar 60 detik sekali dan dari gambar tersebut akan diambil nilai RGB-nya dan akan dihitung nilai Euclidean-nya. Jika nilai Euclidean yang di dapat sudah mencapai nilai Euclidean pada data referensi, maka proses pemanggangan selesai. Kedepannya akan dikembangkan user interface yang memudahkan dalam melakukan pengujian [8].

\section{KeSIMPULAN}

Dari penelitian yang sudah dilakukan didapatkan bahwa perancangan produk yang dibuat dengan teknik pemodelan 3D berhasil diimplementasikan. Selain itu untuk perancangan rangkaian pada setiap komponen juga berhasil diimplementasikan sehingga membuat setiap komponen berfungsi dengan baik. Blade pengaduk dan suhu juga dapat dikontrol secara konstan sehingga dapat mengaduk dan memanggang kopi secara merata.

Untuk sensor pengukur suhu didapatkan bahwa posisi dan jenis sensor menentukan akurasi dari segi pembacaan. Dari hasil percobaan didapatkan bahwa termokopel yang diletakkan pada sisi wadah memberikan hasil bacaan yang lebih baik. Jika dibandingkan dengan penelitian sebelumnya [4] maka untuk jenis sensor termokopel memberikan hasil yang cukup baik namun masih dapat dikembangkan untuk dapat mengukur suhu di dalam biji kopi (endhotermic).

Dapat disimpulkan bahwa produk yang dibuat dapat memenuhi sistem yang sudah dirancang, yaitu roaster dapat bekerja sesuai dengan tingkat kematangan yang diharapkan. 


\section{UCAPAN TERIMA KASIH}

Penulis mengucapkan terimakasih kepada Institut Teknologi Del atas dukungannya sehingga projek penelitian ini dapat terlaksana.

\section{Daftar Pustaka}

[1] J. C. F. Mendonça, A. S. Franca, and L. S. Oliveira, "Physical characterization of non-defective and defective Arabica and Robusta coffees before and after roasting," J. Food Eng., vol. 92, no. 4, pp. 474-479, 2009.

[2] A. Permana, and I. Setiono, "Sistem Pengendalian Suhu dan Pemantauan Kelembaban Biji Kopi Pada Mesin Penyangrai Berbasis Arduino 2560," Gema Teknologi, vol.19, no.2, pp. 19-23, Apr. 2017.

[3] I.J. Sasongko, M. Rivai, "Mesin Pemanggang Biji Kopi dengan Suhu Terkendali Menggunakan Arduino Due," Jurnal Teknik ITS, vol. 7, No. 2, 2018.

[4] F. Sandica, Purwanto, M.A. Muslim, "Penyangrai Biji Kopi Otomatis Untuk Rumah Tangga Berbasis Mikrokontroler Menggunakan Metode Pid Auto Tuning," Jurnal Mahasiswa TEUB,vol. 4, No. 5, 2016.

[5] Mita, A. Abdillah, "Rancang Bangun Alat Penyangrai (Roaster) Kopi Dan Penggiling (Grinder) Kopi Otomatis Berbasis Mikrokontroler," Diploma thesis, Politeknik Perkapalan Negeri Surabaya.

[6] A.A. Latief, "Rancang Bangun Smart Coffee Roasters Berbasis Mikrokontroller," JURNAL IT: Media Infromasi STMIK Handayani Makassar, vol.10, no.1, 2019.

[7] Restiawan, Masde, "Otomatisasi Pengatur Suhu Dan Waktu Pada Penyangrai Kopi (Roaster Coffee) Berbasis Atmega 16 Pada Tampilan Lcd (Liquid Crystal Display)," Tugas Akhir. Tidak diterbitkan. PSD III Teknik Elektro Universitas Diponegoro, Semarang, 2016.

[8] M.F. Waruwu, Mufti, "Sistem Monitoring Suhu dan Relay Pada Mesin Roasting Kopi Dengan Arduino UNO R3," Seminar Nasional Teknologi Komputer \& Sains (SAINTEKS), pp.207-212, Jan. 2019.

[9] I. N. Rosi, "Rancang Bangun Alat Pembuat Minuman Kopi Otomatis Menggunakan Konveyor," Jurnal Ilmiah Mikrotek, vol. 2, no.4, pp.35-45, 2017. 